\title{
32. EXPERIMENTAL PHASE RELATIONS OF BASALTIC ANDESITE FROM HOLE 839B UNDER HYDROUS AND ANHYDROUS CONDITIONS ${ }^{1}$
}

\author{
Glenn A. Gaetani, ${ }^{2}$ Timothy L. Grove, ${ }^{2}$ and Wilfred B. Bryan ${ }^{3}$
}

\begin{abstract}
Experimental phase relations were used to assess the role of volatiles and crustal level fractional crystallization in the petrogenesis of lavas from Hole 839B in the central Lau Basin. Melting experiments were performed on Sample 135-839B-15R-2, 63-67 cm, at $1 \mathrm{~atm}$, anhydrous, and $2 \mathrm{kbar}, \mathrm{H}_{2} \mathrm{O}$-saturated $\left(\sim 6 \mathrm{wt} \% \mathrm{H}_{2} \mathrm{O}\right.$ in the melt) to determine the influence of variable pressure and $\mathrm{H}_{2} \mathrm{O}$ content on phase appearances, mineral chemistry, and liquid line of descent followed during crystallization. The effects of $\mathrm{H}_{2} \mathrm{O}$ are to depress the liquidus by $\sim 100^{\circ} \mathrm{C}$, and to suppress crystallization of plagioclase and orthopyroxene relative to olivine and high-Ca clinopyroxene. At $1 \mathrm{~atm}$, anhydrous, olivine and plagioclase coexist near the liquidus, whereas orthopyroxene and then clinopyroxene appear with decreasing temperature. Crystallization of $50 \mathrm{wt} \%$ produces a residual liquid that is rich in $\mathrm{FeO}^{*}(10.8 \mathrm{wt} \%)$ and poor in $\mathrm{Al}_{2} \mathrm{O}_{3}(13.6 \mathrm{wt} \%)$. At $2 \mathrm{kbar}, \mathrm{H}_{2} \mathrm{O}$-saturated, the liquidus phases are olivine and chromian spinel, with high-Ca clinopyroxene appearing after $\sim 10 \%$ crystallization. Plagioclase saturation is suppressed until $\sim 20 \%$ crystallization has occurred. The residual liquid from $35 \mathrm{wt} \%$ crystallization is rich in $\mathrm{Al}_{2} \mathrm{O}_{3}$ (17.4 wt\%), and poor in $\mathrm{MgO}(4.82 \mathrm{wt} \%)$; it contains moderate $\mathrm{FeO}^{*}(8.2 \mathrm{wt} \%)$, and resembles the low- $\mathrm{MgO}$ andesites recovered from Hole 839B. On the basis of these experiments we conclude that the primitive lavas recovered from Hole 839B have experienced crystallization along the $\mathrm{Ol}+\mathrm{Cpx}$ saturation boundary, under hydrous conditions (an ankaramitic liquid line of descent), and variable amounts of olivine and chromian spinel accumulation. The low- $\mathrm{MgO}$ andesites from Hole $839 \mathrm{~B}$ are the products of hydrous fractional crystallization, at crustal pressures, of a parent magma similar to basaltic andesite Sample 135-839B-15R-2, 63-67 cm.
\end{abstract}

\section{INTRODUCTION}

This paper presents the results of melting experiments designed to identify conditions of crystallization that led to the compositional variations in lavas recovered from Ocean Drilling Program (ODP) Hole $839 \mathrm{~B}$ in the central Lau Basin, and to estimate their pre-eruptive $\mathrm{H}_{2} \mathrm{O}$ contents. These lavas display the strongest affinity to island arc basalts (IAB), in terms of large ion lithophile element (LILE) enrichments and high field strength element (HFSE) depletions (Perfit et al., 1980), of any samples recovered from backarc sites during Leg 135. Hole $839 \mathrm{~B}$ sampled highly vesicular (up to $40 \mathrm{vol} \%$ vesicles) extrusive flows and pillows erupted at the Eastern Lau Spreading Center (ELSC) at approximately $1 \mathrm{Ma}$. The major element systematics of these samples differ from other backarc lavas recovered during Leg 135; they display a positive correlation between $\mathrm{SiO}_{2}$ and $\mathrm{Al}_{2} \mathrm{O}_{3}$, indicating a lack of plagioclase control during fractional crystallization (Parsons, Hawkins, Allan, et al., 1992).

Liquid lines of descent were determined at $1 \mathrm{~atm}$, anhydrous, and $2 \mathrm{kbar}, \mathrm{H}_{2} \mathrm{O}$-saturated ( $\sim 6 \mathrm{wt} \% \mathrm{H}_{2} \mathrm{O}$ in the melt), to examine the influence of variable $\mathrm{H}_{2} \mathrm{O}$ contents on primitive Hole 839B magmas crystallizing at crustal pressures. The addition of $\mathrm{H}_{2} \mathrm{O}$ produces distinctive shifts in the position of the high-Ca clinopyroxene ( $\mathrm{Cpx}$ ) + plagioclase $(\mathrm{Pl})+$ olivine $(\mathrm{Ol})$ and clinopyroxene + plagioclase + orthopyroxene (Opx) saturation boundaries. This leads to an interval of crystallization of high-Ca clinopyroxene and olivine, with a small amount of chromian spinel, similar to the crystallization sequence observed in the lavas recovered from Hole 839B. Crystallization of $35 \mathrm{wt} \%$ produces a residual liquid that is enriched in silica and plagioclase relative to the product of anhydrous crystallization, because of the suppression of plagioclase and orthopyroxene crystallization and

\footnotetext{
'Hawkins, J., Parson, L., Allan, J., et al., 1994. Proc, ODP. Sci. Results, 135: College Station. TX (Ocean Drilling Program).

${ }^{2}$ Department of Earth. Atmospheric, and Planetary Sciences, Massachusetts Institute of Technology, Cambridge, MA 02139, U.S.A.

${ }^{3}$ Woods Hole Oceanographic Institute, Woods Hole, MA 02543, U.S.A.
}

the early appearance of high-Ca clinopyroxene. The evolved liquids produced in our $2 \mathrm{kbar}, \mathrm{H}_{2} \mathrm{O}$-saturated experiments resemble the andesites recovered from the lower portion of Hole $839 \mathrm{~B}$ in that they have high $\mathrm{Al}_{2} \mathrm{O}_{3}$, moderate $\mathrm{CaO}$, and low $\mathrm{MgO}$; however, they are poorer in $\mathrm{FeO}^{\prime}$.

\section{EXPERIMENTAL AND ANALYTICAL METHODS}

\section{Starting Materials}

The starting material for all experiments was natural basaltic andesite Sample 135-839B-15R-2, 63-67 cm (53.3 wt \% SiO $)_{2}$ rock powder produced by grinding in a Spex shatterbox. This sample was chosen to be representative of the Unit 1 lavas recovered from the upper portion of Hole 839B. These lavas contain primarily olivine and high-Ca clinopyroxene phenocrysts; they are characterized by relatively low $\mathrm{Na}_{2} \mathrm{O}(\sim 1.4 \mathrm{wt} \%)$ and $\mathrm{Al}_{2} \mathrm{O}_{3}(\sim 15 \mathrm{wt} \%)$ contents (Parsons, Hawkins, Allan, et al., 1992). The starting material for the $1 \mathrm{~atm}$ experiments was prepared by pressing pellets from 80 to 100 mg of powder, using elvanol as a binder. Pellets were then sintered onto FePt alloy loops, fabricated to minimized Fe-exchange with the sample (Grove, 1981).

\section{1-atm Experiments}

Experiments at $1 \mathrm{~atm}$ were performed by suspending pellets of rock powder on FePt alloy loops in the hot spot of a Deltech DT31VT vertical quenching furnace. The fugacity of oxygen was controlled near the fayalite-magnetite-quartz (FMQ) oxygen buffer using a $\mathrm{CO}_{2}-\mathrm{H}_{2}$ gas mixture, and was monitored using a solid $\mathrm{ZrO}_{2}-\mathrm{CaO}$ electrolyte oxygen sensor calibrated against the $\mathrm{Fe}-\mathrm{FeO}, \mathrm{Ni}-\mathrm{NiO}$, and $\mathrm{Cu}-\mathrm{Cu}_{2} \mathrm{O}$ buffers. Volatilization of $\mathrm{Na}$ from the sample during the experiment was minimized through the use of low gas flow rates and large sample sizes (Tormey et al., 1987). Temperature was monitored using $\mathrm{Pt}-\mathrm{Pt}_{90} \mathrm{Rh}_{10}$ thermocouples, calibrated against the melting point of $\mathrm{NaCl}, \mathrm{Au}$, and Pd on the IPTS 1968 temperature scale (Biggar, 1972). Experiments were terminated by quenching in $\mathrm{H}_{2} \mathrm{O}$. 


\section{2-kbar Experiments}

Experiments at $2 \mathrm{kbar}$ were performed using TZM (titaniumzirconium-molybdenum) and ZHM (zirconium-hafnium carbidemolybdenum) rapid quench cold-seal pressure vessels. Rock powder was placed in a noble metal capsule that was welded closed on the bottom and crimped on the top. This capsule was placed in a larger noble metal capsule along with $\mathrm{H}_{2} \mathrm{O}$ and $\mathrm{Ni}-\mathrm{NiO}$ buffers to control the fugacity of oxygen during the experiment. The outer capsule was then sealed with an arc welder and placed in the bottom of the pressure vessel. The vessel was pumped to $\sim 1.5 \mathrm{kbar}$ at room temperature, using a mixture of $\mathrm{Ar}$ and $\mathrm{CH}_{4}$ gases as a pressure medium, and placed in a Deltech DT31VT vertical furnace with the sample located in the hotspot. The furnace temperature was brought up to experimental conditions over approximately $1 \mathrm{hr}$. Pressure was allowed to increase with increasing temperature until the vessel reached 2 kbar, after which it was maintained by bleeding off small amounts of gas. Experiments were terminated by removing the pressure vessel from the furnace and inverting it, so that the sample slid to the cold end and was rapidly quenched against the cooling head. Experiments were judged successful if the capsule contained $\mathrm{H}_{2} \mathrm{O}$ at the end of the experiment, buffers contained both $\mathrm{Ni}$ and $\mathrm{NiO}$, and the glass was free of quench growth.

The element $\mathrm{Au}$ was used as capsule material for experiments performed at temperatures of $1050^{\circ} \mathrm{C}$ or below. The use of $\mathrm{Au}$ limits the range of temperatures that can be investigated (the 1 -atm melting point of $\mathrm{Au}$ is $1064^{\circ} \mathrm{C}$ ), but it also minimizes the problem of iron loss to the sample container. Experiments above $1050^{\circ} \mathrm{C}$ were performed using $\mathrm{Ag}_{70} \mathrm{Pd}_{30}$ inner and $\mathrm{Au}_{80} \mathrm{Pt}_{20}$ outer capsules. Oxygen buffers consisted of a mixture of $\mathrm{Ni}$ and $\mathrm{NiO}$ powder in a $\mathrm{Pt}$ or $\mathrm{Ag}_{70} \mathrm{Pd}_{30}$ capsule. Buffer capsules were left unsealed so that the $\mathrm{Ni}-\mathrm{NiO}$ mixture remained in contact with the same atmosphere as the experimental charge. Temperature was monitored using $\mathrm{Pt}-\mathrm{Pt}_{90} \mathrm{Rh}_{10}$ thermocouples, calibrated as outlined above for the 1 -atm experiments, located in a well on the outside of the pressure vessel. The temperature difference between the position of the thermocouple and the sample was calibrated several times, and reported experimental temperatures are precise to within $\pm 7^{\circ} \mathrm{C}$. Pressure was monitored with a Heise gauge.

\section{Analytical Methods}

Experimentally produced minerals and glasses, and phenocrysts from Hole 839B lavas were analyzed using the MIT 4-spectrometer JEOL 733 superprobe. On-line data reduction consisted of the matrix corrections of Bence and Albee (1968), with the modifications of Albee and Ray (1970). A 10-nA beam current and 15-kV accelerating potential were used for all analyses. Beam widths were $20 \mu \mathrm{m}$ for hydrous glasses, $10 \mu \mathrm{m}$ for anhydrous glasses, and $\sim 3 \mu \mathrm{m}$ for crystalline phases. Counting times were $5 \mathrm{~s}$ for $\mathrm{Na}$, and up to $40 \mathrm{~s}$ for all other elements.

Analyses of experimentally produced crystalline phases, with the exception of chromian spinel, were performed on rims directly adjacent to glass. This was done to avoid analyzing any unreacted cores remaining from the starting materials. The presence of residual cores is most pronounced in low temperature, anhydrous experiments where the melt fraction is relatively small $(\sim 50 \mathrm{wt} \%)$ and diffusion rates were comparatively slow. Cores were small or absent in hydrous experiments. The presence of unreacted cores indicates that bulk equilibrium was not achieved; however, mineral-melt exchange $K_{D}$ 's (discussed below) indicate that a close approach to surface equilibrium was attained.

\section{EXPERIMENTAL RESULTS}

\section{1 atm, Anhydrous}

At $1 \mathrm{~atm}$, under anhydrous conditions, chromian spinel is the liquidus phase, followed by an assemblage of olivine $\left(\mathrm{Fo}_{85}\right)$, plagioclase $\left(\mathrm{An}_{87}\right)$, and chromian spinel (Table 1). Orthopyroxene coexists
Table 1. Experimental conditions and phase assemblages.

\begin{tabular}{|c|c|c|c|c|c|}
\hline $\begin{array}{l}\text { Run } \\
\text { no, }\end{array}$ & $\begin{array}{c}\text { Temperature } \\
\left({ }^{\circ} \mathrm{C}\right)\end{array}$ & $\log f \mathrm{O}_{2}$ & $\begin{array}{l}\text { Duration } \\
\text { (hr) }\end{array}$ & Run products & $\begin{array}{l}\text { Phase proportions } \\
\text { (wt } \%)\end{array}$ \\
\hline \multicolumn{6}{|c|}{1 atm, anhydrous } \\
\hline 23 & 1210 & -8.52 & 27 & $\mathrm{Gl}, \mathrm{Sp}$ & $100.0: \mathrm{Tr}$ \\
\hline 22 & 1190 & -8.71 & 58 & Gl, Pl, Ol, Sp & $92.2: 4.3: 3.5: \operatorname{Tr}$ \\
\hline 21 & 1180 & -8.86 & 76 & $\mathrm{Gl}, \mathrm{Opx}, \mathrm{Pl}, \mathrm{Ol}$ & $81.7: 5.7: 10.3: 2.3$ \\
\hline 19 & 1170 & -8.94 & 72 & $\mathrm{Gl}, \mathrm{Cpx}, \mathrm{Opx}, \mathrm{Pl}, \mathrm{Ol}$ & $69.7: 1.2: 13.1: 16.0: \mathrm{Tr}$ \\
\hline 17 & 1160 & -9.17 & 72 & $\mathrm{Gl}, \mathrm{Cpx}, \mathrm{Opx}, \mathrm{Pl}$ & $51.0: 8.6: 15.1: 25.3$ \\
\hline 8 & 1150 & -9.06 & 72 & $\mathrm{Gl}, \mathrm{Cpx}, \mathrm{Opx}, \mathrm{Pl}$ & $49.9: 7.9: 16.8: 25.4$ \\
\hline \multicolumn{6}{|c|}{2 kbar, water saturated } \\
\hline 24 & 1100 & - & 3 & Gl, Ol, Sp & $99.0: 1.0: \mathrm{Tr}$ \\
\hline $18^{a}$ & 1075 & - & 13 & $\mathrm{Gl}, \mathrm{Ol}, \mathrm{Sp}$ & $96.0: 4.0: \mathrm{Tr}$ \\
\hline 12 & 1050 & - & 24 & Gl, Cpx, Ol, Sp & $88.6: 5.7: 5.7: \mathrm{Tr}$ \\
\hline $7^{b}$ & 1035 & - & 24 & Gl, Cpx, OI, Sp & $86.7: 7.1: 6.2: \mathrm{Tr}$ \\
\hline 4 & 1035 & - & 24 & $\mathrm{Gl}, \mathrm{Cpx}, \mathrm{Ol}, \mathrm{Sp}$ & $83.2: 10.2: 6.6: \mathrm{Tr}$ \\
\hline 5 & 1020 & - & 24 & Gl, Cpx, Ol, Pl, Sp & $79.7: 12.7: 7.1: 0.5: \mathrm{Tr}$ \\
\hline 6 & 1005 & - & 24 & Gl, Cpx, Ol, Pl, Sp & $65.4: 15.8: 9.1: 9.7: \mathrm{Tr}$ \\
\hline
\end{tabular}

Notes: $\mathrm{Tr}=$ trace, $\mathrm{Gl}=$ glass, $\mathrm{Sp}=$ chromian spinel, $\mathrm{Pl}=$ plagioclase, $\mathrm{Ol}=$ olivine, $\mathrm{Opx}=$ orthopyroxene, and $\mathrm{Cpx}=$ high-Ca clinopyroxene.

${ }^{a} \mathrm{O}_{2}<\mathrm{NiNiO}$.

${ }^{b} \mathrm{ZHM}$ pressure vessel.

with olivine and plagioclase at $1180^{\circ} \mathrm{C}$, and the melt reaches the "olivine out" reaction point (Grove and Baker, 1984) at $1170^{\circ} \mathrm{C}$, when the melt saturates with high-Ca clinopyroxene. The melt remains on the $\mathrm{Cpx}+\mathrm{Opx}+\mathrm{Pl}$ saturation boundary to the lowest temperature investigated $\left(1150^{\circ} \mathrm{C}\right)$.

Melt compositions display the variations typical of basalt crystallization under anhydrous conditions (Table 2). $\mathrm{CaO}, \mathrm{Al}_{2} \mathrm{O}_{3}$, and $\mathrm{MgO}$ all decrease monotonically with decreasing melt fraction $(\mathrm{F})$, because of the crystallization of plagioclase and ferromagnesian silicates, whereas $\mathrm{SiO}_{2}, \mathrm{Na}_{2} \mathrm{O}, \mathrm{K}_{2} \mathrm{O}, \mathrm{TiO}_{2}$ and $\mathrm{FeO}^{3}$ increase. The result of $\sim 50 \%$ crystallization (by weight) is an iron-rich $\left(10.8 \mathrm{wt} \% \mathrm{FeO}^{*}\right)$, alumina-poor $(13.6 \mathrm{wt} \%)$ basaltic andesite $\left(54.9 \mathrm{wt} \% \mathrm{SiO}_{2}\right)$.

The composition of experimentally produced pyroxenes are shown in Figure 1 and reported in Table 2. The experiment performed at $1180^{\circ} \mathrm{C}$ contained orthopyroxene, and those from $1170^{\circ} \mathrm{C}$ to $1150^{\circ} \mathrm{C}$ contained coexisting low- and high-Ca pyroxenes. All high-Ca pyroxene compositions plot in the augite field of the pyroxene quadrilateral (Poldervaart and Hess, 1951). Olivine compositions range from $\mathrm{Fo}_{85}$ to $\mathrm{Fo}_{81}$, and plagioclase compositions range from $\mathrm{An}_{87}$ to $\mathrm{An}_{77}$ (Table 2). The mean Fe-Mg mineral-melt exchange $K_{D}$ 's are $0.30 \pm 0.01$ for olivine, $0.25 \pm 0.03$ for orthopyroxene, and $0.26 \pm 0.01$ for high-Ca pyroxene. The mean plagioclase-melt Ca-Na exchange $\mathrm{K}_{\mathrm{D}}$ is $1.38 \pm$ 0.21 . These $K_{D}$ 's are similar to the experimentally determined values of 0.30 for olivine (Roeder and Emslie, 1970), 0.23 for pyroxene (Grove and Bryan, 1983), and 1.13 for plagioclase (Grove et al., 1990), indicating a close approach to equilibrium between the surface of the crystals and the surrounding melt.

\section{2 kbar, $\mathrm{H}_{2} \mathrm{O}$ Saturated}

The liquidus phases at $2 \mathrm{kbar}, \mathrm{H}_{2} \mathrm{O}$-saturated, are olivine $\left(\mathrm{Fo}_{86}\right)$ and chromian spinel. The highest temperature experiment contained only $\sim 1 \%$ olivine phenocrysts, implying that $1100^{\circ} \mathrm{C}$ is close to the liquidus temperature (Table 1). This indicates that the liquidus has been depressed by $\sim 100^{\circ} \mathrm{C}$ relative to anhydrous conditions. High-Ca clinopyroxene (endiopside) joins the crystallizing assemblage between $1075^{\circ}$ and $1050^{\circ} \mathrm{C}$, and becomes the dominant crystallizing phase until the melt becomes saturated with calcic plagioclase $\left(A n_{94}\right)$ at $1020^{\circ} \mathrm{C}$.

The variations in melt composition produced at $2 \mathrm{kbar}$ with $\sim 6 \mathrm{wt} \%$ $\mathrm{H}_{2} \mathrm{O}$ in the melt are distinct from those produced at $\mathrm{l}$ atm, anhydrous (Table 3). $\mathrm{SiO}_{2}, \mathrm{Na}_{2} \mathrm{O}, \mathrm{TiO}_{2}$, and $\mathrm{K}_{2} \mathrm{O}$ all increase with decreasing $\mathrm{F}$, whereas $\mathrm{MgO}$ decreases, as was the case in the anhydrous experiments. The major difference caused by $\mathrm{H}_{2} \mathrm{O}$ saturation at 2 kbar is that $\mathrm{SiO}_{2}$ increases and $\mathrm{MgO}$ decreases more rapidly in the residual liquid. In contrast with anhydrous crystallization, $\mathrm{FeO}^{\prime \prime}$ decreases slightly with decreasing $\mathrm{F}$. The behavior of $\mathrm{CaO}$ and $\mathrm{Al}_{2} \mathrm{O}_{3}$ are controlled by the crystallization of high- $\mathrm{Ca}$ clinopyroxene and plagioclase. $\mathrm{CaO}$ in- 
Table 2. Electron microprobe analyses of run products from $1 \mathrm{~atm}$, anhydrous experiments.

\begin{tabular}{|c|c|c|c|c|c|c|c|c|c|c|c|c|c|c|}
\hline $\begin{array}{l}\text { Run } \\
\text { no. }\end{array}$ & Phase & $\begin{array}{c}\text { Analyses } \\
(N)\end{array}$ & $\mathrm{SiO}_{2}$ & $\mathrm{TiO}_{2}$ & $\mathrm{Al}_{2} \mathrm{O}_{3}$ & $\mathrm{Cr}_{2} \mathrm{O}_{3}$ & $\mathrm{FeO}^{*}$ & $\mathrm{MnO}$ & $\mathrm{MgO}$ & $\mathrm{CaO}$ & $\mathrm{Na}_{2} \mathrm{O}$ & $\mathrm{K}_{2} \mathrm{O}$ & $\mathrm{P}_{2} \mathrm{O}_{5}$ & Total \\
\hline 23 & GI & 10 & $53.3(2)$ & $0.60(3)$ & $15.16(8)$ & $0.05(3)$ & $8.85(8)$ & $0.22(2)$ & $9.36(5)$ & $11.3(1)$ & $1.48(5)$ & $0.30(2)$ & $0.11(3)$ & 100.73 \\
\hline 22 & $\mathrm{Pl}$ & 5 & $47.9(5)$ & - & $31.9(12)$ & - & $1.1(3)$ & - & $0.9(4)$ & $17.1(5)$ & $1.36(6)$ & $0.07(1)$ & - & 100.33 \\
\hline \multirow[t]{2}{*}{21} & Gl & 10 & $53.5(1)$ & $0.73(3)$ & $14.26(7)$ & $0.07(3)$ & $9.4(1)$ & $0.19(3)$ & $7.91(9)$ & $11.5(2)$ & $1.55(6)$ & $0.30(1)$ & $0.16(2)$ & 99.57 \\
\hline & Opx & 7 & $55.8(3)$ & $0.11(2)$ & $1.0(2)$ & $0.4(1)$ & $9.9(3)$ & $0.23(1)$ & $30.1(4)$ & $2.5(1)$ & $0.01(1)$ & - & - & 100.05 \\
\hline \multirow[t]{5}{*}{19} & GI & 10 & $53.4(2)$ & $0.87(3)$ & $13.93(9)$ & $0.05(2)$ & $10.3(1)$ & $0.24(5)$ & $7.5(1)$ & $11.4(1)$ & $1.66(9)$ & $0.36(2)$ & $0.17(3)$ & 99.88 \\
\hline & Cpx & 8 & $52.9(4)$ & $0.22(2)$ & $2.5(4)$ & $0.6(3)$ & $6.60(3)$ & $0.17(2)$ & $18.5(4)$ & $18.9(8)$ & $0.13(2)$ & - & - & 100.52 \\
\hline & Opx & 7 & $55.7(2)$ & $0.09(1)$ & $1.0(1)$ & $0.37(3)$ & $10.8(1)$ & $0.25(2)$ & $29.5(4)$ & $2.46(7)$ & $0.02(1)$ & - & - & 100.19 \\
\hline & ol & 5 & $39.1(4)$ & $0.00(1)$ & $0.07(5)$ & $0.04(1)$ & $17.7(1)$ & $0.28(3)$ & $42.6(5)$ & $0.39(5)$ & - & - & - & 100.18 \\
\hline & Pl & 4 & $48.2(7)$ & - & $32.2(6)$ & - & $0.80(5)$ & - & $0.5(1)$ & $16.8(3)$ & $1.7(2)$ & $0.05(1)$ & - & 100.25 \\
\hline \multirow[t]{2}{*}{17} & Gi & 10 & $54.2(4)$ & $1.0(1)$ & $13.7(1)$ & $0.01(2)$ & $11.2(2)$ & $0.21(4)$ & $6.5(1)$ & $10.6(2)$ & $1.9(1)$ & $0.42(2)$ & $0.20(1)$ & 99.94 \\
\hline & Cpx & 7 & $52.8(7)$ & $0.27(6)$ & $2.3(6)$ & $0.5(2)$ & $8.3(4)$ & $0.24(4)$ & $18.2(5)$ & $17.6(7)$ & $0.12(3)$ & - & - & 100.33 \\
\hline 8 & $\mathrm{Pl}$ & 4 & $49.8(8)$ & - & $31.0(3)$ & - & $0.91(7)$ & - & $0.47(4)$ & $15.9(5)$ & $2.3(3)$ & $0.07(2)$ & - & 100.45 \\
\hline
\end{tabular}

Notes: Units in parentheses represent 1 standard deviation of least units cited, based on replicate analyses; thus, $53.3(2)$ should be read as $53.3 \pm 0.2$. Abbreviations as in Table 1, with the addition of $N=$ number of analyses.

Table 3. Electron microprobe analyses of run products from $2 \mathrm{kbar}$, water-saturated experiments.

\begin{tabular}{|c|c|c|c|c|c|c|c|c|c|c|c|c|c|c|}
\hline $\begin{array}{l}\text { Run } \\
\text { no. }\end{array}$ & Phase & $\begin{array}{c}\text { Analyses } \\
(N)\end{array}$ & $\mathrm{SiO}_{2}$ & $\mathrm{TiO}_{2}$ & $\mathrm{Al}_{2} \mathrm{O}_{3}$ & $\mathrm{Cr}_{2} \mathrm{O}_{3}$ & $\mathrm{FeO}^{*}$ & $\mathrm{MnO}$ & $\mathrm{MgO}$ & $\mathrm{CaO}$ & $\mathrm{Na}_{2} \mathrm{O}$ & $\mathrm{K}_{2} \mathrm{O}$ & $\mathrm{P}_{2} \mathrm{O}_{5}$ & Total \\
\hline \multirow[t]{2}{*}{24} & Gl & 10 & $53.1(1)$ & $0.63(3)$ & $15.12(8)$ & $0.01(2)$ & $8.8(1)$ & $0.18(3)$ & $8.93(5)$ & $11.43(9)$ & $1.5(1)$ & $0.27(2)$ & $0.12(2)$ & 93.82 \\
\hline & OI & 5 & $40.0(4)$ & $0.02(2)$ & $0.06(3)$ & $0.10(2)$ & $13.6(6)$ & $0.24(2)$ & $45.6(3)$ & $0.32(2)$ & - & - & - & 99.94 \\
\hline \multirow[t]{3}{*}{18} & Gl & 10 & $53.3(2)$ & $0.65(2)$ & $15.6(8)$ & $0.07(3)$ & $8.6(1)$ & $0.16(2)$ & $7.85(6)$ & $11.76(8)$ & $1.60(9)$ & $0.30(2)$ & $0.15(2)$ & 93.73 \\
\hline & $\mathrm{Ol}$ & 5 & $39.8(4)$ & $0.03(2)$ & $0.07(1)$ & $0.11(2)$ & $15.4(5)$ & $0.23(3)$ & $44.5(7)$ & $0.29(2)$ & - & - & - & 100.43 \\
\hline & Sp & 5 & $0.06(7)$ & $0.5(2)$ & $12.8(23)$ & $49.2(47)$ & $24.9(25)$ & $0.36(3)$ & $10.2(4)$ & $0.36(5)$ & - & - & - & 98.38 \\
\hline \multirow[t]{4}{*}{12} & Gl & 10 & $54.0(2)$ & $0.70(4)$ & $16.9(1)$ & $0.03(2)$ & $8.27(7)$ & $0.19(4)$ & $6.66(5)$ & $11.21(2)$ & $1.6(1)$ & $0.31(1)$ & $0.14(2)$ & 94.52 \\
\hline & Cpx & 7 & $53.0(3)$ & $0.24(2)$ & $2.6(3)$ & $0.79(9)$ & $5.3(4)$ & $0.15(3)$ & $17.4(3)$ & $21.5(4)$ & $0.13(1)$ & - & - & 101.11 \\
\hline & Ol & 5 & $39.5(4)$ & $0.01(1)$ & $0.06(3)$ & $0.03(2)$ & $16.5(3)$ & $0.25(2)$ & $43.4(6)$ & $0.4(2)$ & - & - & - & 100.15 \\
\hline & $\mathrm{Sp}$ & 2 & $0.21(3)$ & $0.5(2)$ & $14.7(17)$ & $47.9(36)$ & $25.0(10)$ & $0.33(0)$ & $10.2(2)$ & $0.34(1)$ & - & - & - & 99.18 \\
\hline \multirow[t]{3}{*}{7} & Gl & 10 & $54.0(6)$ & $0.67(2)$ & $17.2(2)$ & $0.00(0)$ & $8.2(2)$ & $0.14(4)$ & $6.40(7)$ & $11.1(2)$ & $1.8(1)$ & $0.35(2)$ & $0.16(1)$ & 94.11 \\
\hline & Cpx & 10 & $52.6(6)$ & $0.26(3)$ & $2.8(5)$ & $0.7(1)$ & $5.1(2)$ & $0.15(2)$ & $16.9(4)$ & $21.8(3)$ & $0.14(2)$ & - & - & 100.45 \\
\hline & ol & 5 & $39.0(3)$ & $0.01(1)$ & $0.04(3)$ & $0.02(1)$ & $18.1(4)$ & $0.25(2)$ & $42.4(3)$ & $0.27(2)$ & - & - & - & 100.09 \\
\hline \multirow[t]{3}{*}{4} & Gl & 10 & $54.4(1)$ & $0.70(5)$ & $17.7(1)$ & $0.03(2)$ & $8.0(1)$ & $0.22(4)$ & $5.85(6)$ & $10.8(1)$ & $1.85(9)$ & $0.34(1)$ & $0.20(3)$ & 92.84 \\
\hline & Cpx & 10 & $52.4(4)$ & $0.33(9)$ & $2.9(3)$ & $0.6(1)$ & $6.4(9)$ & $0.18(3)$ & $16.9(5)$ & $20.5(7)$ & $0.14(2)$ & - & - & 100.35 \\
\hline & Ol & 5 & $38.9(4)$ & $0.03(0)$ & $0.05(2)$ & $0.04(1)$ & $18.5(4)$ & $0.26(2)$ & $42.0(3)$ & $0.24(2)$ & - & - & - & 100.02 \\
\hline \multirow[t]{5}{*}{5} & Gl & 10 & $54.5(3)$ & $0.74(3)$ & $18.18(9)$ & $0.01(2)$ & $8.1(2)$ & $0.20(5)$ & $5.49(6)$ & $10.5(1)$ & $1.81(8)$ & $0.35(1)$ & - & 93.31 \\
\hline & Cpx & 10 & $52.0(4)$ & $0.35(7)$ & $3.2(5)$ & $0.6(1)$ & $6.2(7)$ & $0.16(4)$ & $16.2(3)$ & $21.0(6)$ & $0.14(2)$ & - & - & 99.85 \\
\hline & of & 5 & $38.6(2)$ & $0.01(1)$ & $0.07(7)$ & $0.07(3)$ & $19.3(4)$ & $0.25(3)$ & $41.0(4)$ & $0.30(5)$ & - & - & - & 99.60 \\
\hline & Pl & 5 & $45.4(5)$ & - & $33.6(7)$ & - & $0.7(1)$ & - & $0.2(1)$ & $18.8(2)$ & $0.65(5)$ & $0.02(2)$ & - & 99.37 \\
\hline & Sp & 2 & $0.13(2)$ & $0.5(2)$ & $12.1(11)$ & $47.4(45)$ & $30.1(32)$ & $0.33(2)$ & $7.8(4)$ & $0.30(3)$ & - & - & - & 98.66 \\
\hline \multirow[t]{4}{*}{6} & $\mathrm{Gl}$ & 10 & $56.3(2)$ & $0.81(3)$ & $17.4(1)$ & $0.05(2)$ & $8.2(1)$ & $0.20(5)$ & $4.82(4)$ & $9.5(1)$ & $2.13(6)$ & $0.45(3)$ & $0.18(2)$ & 92.57 \\
\hline & $\mathrm{Cpx}$ & 10 & $52.3(5)$ & $0.36(6)$ & $2.6(7)$ & $0.49(7)$ & $7.2(3)$ & $0.18(5)$ & $16.7(6)$ & $20.0(3)$ & $0.16(3)$ & - & - & 99.99 \\
\hline & Ol & 5 & $38.1(2)$ & $0.02(1)$ & $0.05(2)$ & $0.07(0)$ & $21.7(2)$ & $0.30(1)$ & $39.0(4)$ & $0.26(2)$ & - & - & - & 99.50 \\
\hline & $\mathrm{Pl}$ & 10 & $46.3(6)$ & - & $34.1(6)$ & - & $0.8(1)$ & - & $0.17(3)$ & $18.1(5)$ & $1.1(3)$ & $0.01(1)$ & - & 100.58 \\
\hline
\end{tabular}

Notes: All glass compositions are normalized to $100 \%$ on an anhydrous basis. Original unnormalized total is reported. Abbreviations are as in Table 1, with the addition of $N=$ number of analyses.

creases with the first few percent crystallization and then decreases steadily following pyroxene saturation. $\mathrm{Al}_{2} \mathrm{O}_{3}$ increases from 15.1 to $18.2 \mathrm{wt} \%$, before plagioclase saturation (at $\mathrm{F} \approx 80 \mathrm{wt} \%$ ), and then decreases steadily. The residual melt from $\sim 35$ wt\% crystallization is a basaltic andesite $\left(56.3 \mathrm{wt} \% \mathrm{SiO}_{2}\right)$ with relatively high alumina (17.4 wt $\%$ ), moderate $\mathrm{FeO}^{\circ}(8.2 \mathrm{wt} \%)$, and relatively low $\mathrm{MgO}$ (4.82 wt \%). It is similar in composition to andesites typically found in arc environments (e.g., Gill, 1981).

Figure 1 shows the composition of experimentally produced high$\mathrm{Ca}$ pyroxenes. They are considerably more calcic than those in equilibrium with the $\mathrm{I}$ atm, anhydrous, melts. Pyroxenes from the high-temperature experiments plot in the endiopside field of the pyroxene quadrilateral, and their compositions move into the $\mathrm{Mg}$-rich part of the augite field with decreasing temperature. Olivine compositions range from $\mathrm{Fo}_{86}$ to $\mathrm{Fo}_{76}$, whereas plagioclase compositions range from $\mathrm{An}_{94}$ to $\mathrm{An}_{90}$. The mean $\mathrm{Fe}-\mathrm{Mg}$ mineral-melt exchange $\mathrm{K}_{\mathrm{D}}$ 's are $0.32 \pm 0.01$ for olivine and $0.26 \pm 0.02$ for high-Ca clinopy- roxene. The mean plagioclase-melt Ca- $\mathrm{Na}$ exchange $\mathrm{K}_{\mathrm{D}}$ is $4.3 \pm 0.9$. The values for olivine and pyroxene are again close to previously determined values; however, the plagioclase-melt $K_{D}$ is lower than the value of 5.5 reported by Sisson and Grove (1993a) from their 2 kbar, $\mathrm{H}_{2} \mathrm{O}$-saturated experiments.

\section{PHENOCRYST COMPOSITIONS FROM UNIT 1 LAVAS}

Phenocryst compositions were analyzed by electron microprobe from thin sections of samples from Hole 839B located below (Sample 135-839B-15R-3, 72-76 cm) and above (Sample 135-839B-14R-2, 1-8 cm) Sample 135-839B-15R-2, 63-67 cm, to help constrain the petrogenesis of Unit 1 lavas (Table 4). Sample 135-839B-15R-3, $72-76 \mathrm{~cm}$, contains olivine, high-Ca clinopyroxene, and chromian spinel phenocrysts, with plagioclase occurring as occasional glomerocrystic intergrowths with clinopyroxene. Sample 135-839B-14R-2, 
Table 4. Electron microprobe analyses of phenocrysts from Unit 1 lavas.

\begin{tabular}{|c|c|c|c|c|c|c|c|c|c|c|c|c|c|c|}
\hline Phase & Notes & $\begin{array}{c}\text { Analyses } \\
(N)\end{array}$ & $\mathrm{SiO}_{2}$ & $\mathrm{TiO}_{2}$ & $\mathrm{Al}_{2} \mathrm{O}_{3}$ & $\mathrm{Cr}_{2} \mathrm{O}_{3}$ & $\mathrm{FeO}^{\circ}$ & $\mathrm{MnO}$ & $\mathrm{MgO}$ & $\mathrm{CaO}$ & $\mathrm{Na}_{2} \mathrm{O}$ & $\mathrm{K}_{2} \mathrm{O}$ & $\mathrm{NiO}$ & Total \\
\hline \multicolumn{15}{|c|}{ Sample $135-839 \mathrm{~B}-15 \mathrm{R}-3,72-76 \mathrm{~cm}:$} \\
\hline \multirow[t]{5}{*}{$\mathrm{Cpx}$} & & 3 & $52.0(9)$ & $0.3(1)$ & $2.9(10)$ & $0.7(2)$ & $5.8(3)$ & $0.11(3)$ & $17.9(8)$ & 20.4(5) & $0.10(3)$ & - & - & 100.21 \\
\hline & & 3 & $52.6(1)$ & $0.26(2)$ & $2.24(8)$ & $0.4(1)$ & $6.3(5)$ & $0.14(1)$ & $17.9(2)$ & $19.8(5)$ & $0.08(2)$ & - & - & 99.72 \\
\hline & & 4 & $52.4(7)$ & $0.24(8)$ & $2.4(7)$ & $0.5(2)$ & $5.7(3)$ & $0.15(3)$ & $18.1(4)$ & $20.4(3)$ & $0.07(2)$ & - & - & 99.96 \\
\hline & Core & 2 & $51.9(2)$ & $0.26(3)$ & $3.00(7)$ & $1.1(1)$ & $4.88(0)$ & $0.07(3)$ & $17.5(1)$ & $21.2(0)$ & $0.11(2)$ & - & - & 100.02 \\
\hline & Rim & 2 & $52.0(8)$ & $0.30(7)$ & $2.70(8)$ & $0.42(2)$ & $6.03(8)$ & $0.15(1)$ & $17.9(4)$ & $20.1(3)$ & $0.08(1)$ & - & - & 99.68 \\
\hline \multirow[t]{4}{*}{$\mathrm{Ol}$} & & 2 & $39.3(0)$ & $0.04(1)$ & $0.06(2)$ & $0.07(1)$ & $17.1(0)$ & $0.28(0)$ & $43.0(2)$ & $0.24(1)$ & - & - & $0.14(0)$ & 100.23 \\
\hline & Core & 2 & $40.1(1)$ & $0.04(1)$ & $0.05(1)$ & $0.08(0)$ & $11.3(1)$ & $0.18(1)$ & $47.1(1)$ & $0.19(0)$ & - & - & $0.33(1)$ & 99.37 \\
\hline & Rim & 2 & $40.2(0)$ & $0.05(1)$ & $0.05(2)$ & $0.09(0)$ & $13.5(8)$ & $0.22(2)$ & $46.1(7)$ & $0.20(1)$ & - & - & $0.28(2)$ & 100.69 \\
\hline & & 2 & $39.2(1)$ & $0.05(2)$ & $0.05(1)$ & $0.06(1)$ & $17.5(1)$ & $0.29(1)$ & $42.7(2)$ & $0.18(0)$ & - & - & $0.12(2)$ & 100.15 \\
\hline \multirow[t]{4}{*}{$\mathrm{PI}$} & Cpx incl. & 2 & $45.8(1)$ & - & $33.4(2)$ & - & $0.85(2)$ & - & $0.19(0)$ & $17.8(1)$ & $1.18(1)$ & $0.00(0)$ & - & 99.22 \\
\hline & & 2 & $46.7(2)$ & - & $33.4(1)$ & - & $0.68(1)$ & - & $0.21(2)$ & $17.8(1)$ & $1.21(4)$ & $0.01(1)$ & - & 100.01 \\
\hline & Cpx incl. & 2 & $47.1(2)$ & - & $33.3(1)$ & - & $0.81(2)$ & - & $0.23(0)$ & $17.6(2)$ & $1.42(6)$ & $0.01(1)$ & - & 100.47 \\
\hline & & 2 & $46.6(6)$ & - & $33.6(1)$ & - & $0.63(7)$ & - & $0.19(0)$ & $18.0(4)$ & $1.2(1)$ & $0.00(0)$ & - & 100.22 \\
\hline $\mathrm{Sp}$ & Ol incl. & 1 & 0.00 & 0.53 & 11.8 & 44.0 & 32.1 & 0.44 & 8.38 & 0.04 & - & - & 0.22 & 97.51 \\
\hline \multicolumn{15}{|c|}{ Sample 135-839B-14R-2, $1-8 \mathrm{~cm}$ : } \\
\hline Cpx & & 3 & $52.7(3)$ & $0.24(3)$ & $2.2(6)$ & $0.4(2)$ & $6.5(4)$ & $0.15(1)$ & $18.2(2)$ & $19.7(3)$ & $0.14(1)$ & - & - & 100.23 \\
\hline Opx & Rim & 3 & $54.3(1)$ & $0.16(1)$ & $1.63(5)$ & $0.15(1)$ & $12.7(1)$ & $0.27(1)$ & $28.6(0)$ & $1.97(5)$ & $0.02(2)$ & - & - & 99.80 \\
\hline Opx & Rim & 3 & $54.1(1)$ & $0.18(2)$ & $1.57(9)$ & $0.05(3)$ & $13.8(1)$ & $0.31(2)$ & $27.6(1)$ & $2.07(8)$ & $0.04(3)$ & - & - & 99.72 \\
\hline oi & Core & 3 & $39.1(2)$ & $0.01(1)$ & $0.01(1)$ & $0.09(1)$ & $20.4(4)$ & $0.29(0)$ & $41.2(4)$ & $0.22(1)$ & - & - & $0.16(1)$ & 101.48 \\
\hline \multirow[t]{4}{*}{$\mathrm{PI}$} & & 2 & $45.8(1)$ & - & $33.7(2)$ & - & $0.88(6)$ & - & $0.15(3)$ & $18.2(1)$ & $1.02(2)$ & $0.02(2)$ & - & 99.77 \\
\hline & & 2 & $45.8(2)$ & - & $34.0(0)$ & - & $0.89(5)$ & - & $0.17(1)$ & $18.2(1)$ & $1.03(1)$ & $0.03(3)$ & - & 100.12 \\
\hline & Core & 2 & $45.7(1)$ & - & $34.2(1)$ & - & $0.70(4)$ & - & $0.15(1)$ & $18.5(2)$ & $0.94(4)$ & $0.02(0)$ & - & 100.21 \\
\hline & Rim & 2 & $51.4(2)$ & - & $30.2(0)$ & - & $1.03(0)$ & - & $0.16(2)$ & $14.5(1)$ & $3.17(5)$ & $0.02(1)$ & - & 100.48 \\
\hline \multirow[t]{2}{*}{ Sp } & $\mathrm{Ol}$ incl. & 1 & 0.12 & 0.31 & 9.32 & 52.4 & 28.5 & 0.23 & 8.14 & 0.04 & - & - & 0.16 & 99.22 \\
\hline & Ol incl. & 1 & 0.09 & 0.47 & 13.5 & 43.5 & 31.8 & 0.21 & 8.29 & 0.05 & - & - & 0.10 & 98.01 \\
\hline
\end{tabular}

Notes: Abbreviations as in Table 1, with the addition of $N=$ number of analyses and incl. = inclusion.

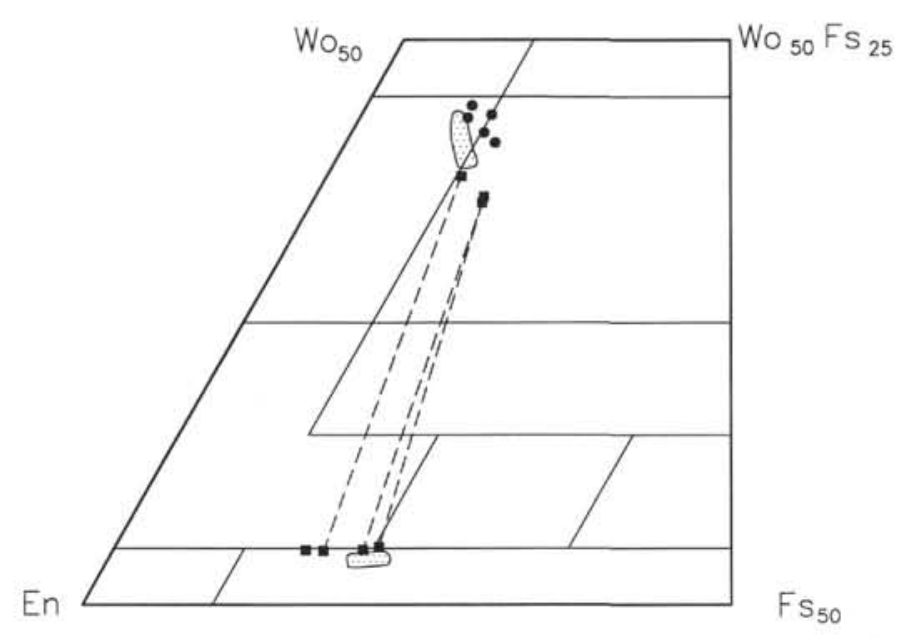

Figure 1. Composition of pyroxenes produced in anhydrous (filled squares) and water-saturated (filled circles) experiments, and phenocrysts from Hole 839B lavas (shaded fields) projected onto the Wo-En-Fs (molar) plane. Dashed lines connect coexisting high- and low-Ca pyroxenes.

1-8 cm, contains orthopyroxene, commonly cored by olivine, highCa clinopyroxene, chromian spinel, and some plagioclase.

The range of high-Ca clinopyroxene and orthopyroxene compositions found in thin section are compared with experimentally produced pyroxenes in Figure 1. The clinopyroxenes at the high-Ca end contain $\sim 21 \mathrm{wt} \% \mathrm{CaO}$, and are similar to those produced in the 2-kbar experiments, whereas the low-Ca end of the trend, defined by an augite from Sample 135-839B-14R-2, 1-8 cm, approaches the pyroxenes from the 1-atm experiments. The orthopyroxenes are slightly less calcic than those from the 1-atm experiments, but they have similar Fe/Mg ratios. Olivine compositions in Sample 135-839B-15R-3, 72$76 \mathrm{~cm}$, range from $\mathrm{Fo}_{88}$ (core composition) to $\mathrm{Fo}_{81}$. The olivines analyzed in Sample 135-839B-14R-2, 1-8 cm (orthopyroxene cores), are $\mathrm{Fo}_{82}$ and $\mathrm{FO}_{78}$. The plagioclase phenocrysts analyzed in both thin sections are Ca-rich, with $\mathrm{An}_{89}$ in Sample 135-839B-15R-3, 72-76 $\mathrm{cm}$, and $\mathrm{An}_{91}$ in Sample 135-839B-14R-2, 1-8 cm. One analyzed grain consists of an $\mathrm{An}_{92}$ core surrounded by an $\mathrm{An}_{72}$ rim $\sim 10 \mu \mathrm{m}$ wide.

\section{DISCUSSION}

Backarc basin basalts (BAB) exhibit a compositional range from MORB-like to IAB-like, and are variably enriched in alkalis and volatiles, especially $\mathrm{H}_{2} \mathrm{O}$ (Hart et al., 1972). Experimental studies have demonstrated that the presence of $\mathrm{H}_{2} \mathrm{O}$ changes the phase relations of basaltic magmas (e.g., Baker and Eggler, 1987). Therefore, to understand the melting and crystallization histories of $\mathrm{BAB}$, knowledge of both hydrous and anhydrous phase boundaries is necessary.

The Pl-Cpx- $\mathrm{SiO}_{2}$ pseudo-ternary diagram in Figure 2 (left) shows the glass compositions produced in both the anhydrous and $\mathrm{H}_{2} \mathrm{O}$ saturated experiments recalculated from weight percent oxides to mineral components $\left(\mathrm{Ol}-\mathrm{Cpx}-\mathrm{Pl}-\mathrm{SiO}_{2}\right)$, using the scheme of Tormey et al. (1987), and projected from $\mathrm{Ol}$ onto the $\mathrm{Pl}-\mathrm{Cpx}-\mathrm{SiO}_{2}$ plane. The projection from $\mathrm{Ol}$ was chosen because all of the hydrous experiments are olivine saturated, and this projection shows compositional variations caused by crystallization of both clinopyroxene and plagioclase. Experimentally determined phase boundaries are shown as dotted ( $1 \mathrm{~atm}$, anhydrous) and dashed ( $2 \mathrm{kbar}, \mathrm{H}_{2} \mathrm{O}$-saturated) curves. The most pronounced effect of high $\mathrm{H}_{2} \mathrm{O}$ content on phase relations is a shift of the $\mathrm{Ol}+\mathrm{Pl}+\mathrm{Cpx}$ saturation boundary toward the $\mathrm{Pl}$ corner of the pseudo-ternary.

The $\mathrm{Pl}-\mathrm{Cpx}-\mathrm{Ol}$ pseudo-ternary in Figure 2 (right) shows the experimentally produced glass compositions projected from $\mathrm{SiO}_{2}$ onto the Pl-Cpx-Ol plane. The projection from silica is advantageous because the $\mathrm{Ol}+\mathrm{Cpx}+\mathrm{Pl}$ boundary is nearly perpendicular to the $\mathrm{Ol}-\mathrm{Cpx}-\mathrm{Pl}$ plane, pointing toward the silica apex, and so this boundary projects as a point. A shift of the $\mathrm{Ol}+\mathrm{Cpx}+\mathrm{Pl}$ saturation boundary toward the $\mathrm{Pl}$ apex is evident, similar in magnitude to that recognized by Sisson and Grove (1993a) in both natural and simple (Fo-Di-An$\mathrm{H}_{2} \mathrm{O}$ ) systems. The present experiments define the position of the $\mathrm{Ol}$ $+\mathrm{Cpx}$ saturation boundary at $2 \mathrm{kbar}, \mathrm{H}_{2} \mathrm{O}$-saturated. Materials balance calculations of experiments saturated with an assemblage of olivine + high-Ca clinopyroxene (+ chromian spinel) were used to estimate the proportions of pyroxene and olivine that crystallize as the melt evolves along the $\mathrm{Ol}+\mathrm{Cpx}$ saturation boundary. Calculations 
were performed using the glass composition from a high-temperature experiment (e.g., Experiment $\# 12$ at $1050^{\circ} \mathrm{C}$ ) with the glass and mineral compositions from a lower temperature experiment (Experiment $\# 7$ at $1035^{\circ} \mathrm{C}$ ) (Bryan et al., 1969). The resulting ratio of olivine to pyroxene approximates the proportion of minerals that would be removed from the melt during a process approaching fractional crystallization. The proportion of pyroxene to olivine calculated using this method is $\sim 78: 22$, a ratio that shows little variation among the three experiments. This is an indication that the $\mathrm{Ol}+\mathrm{Cpx}$ boundary has very little curvature over this part of composition space.

\section{Comparison of Experimental Results with Lavas from Ares and Backarcs}

Perfit et al. (1980), among others, suggest that an interval of olivine + high-Ca clinopyroxene ( \pm chromian spinel) crystallization, such as that produced in our $\mathrm{H}_{2} \mathrm{O}$-saturated experiments, is important in the evolution of primitive arc-related magmas during crystallization differentiation. Early fractional crystallization of MORB is controlled primarily by olivine and plagioclase fractionation leading to, for example, a positive correlation between $\mathrm{MgO}$ and $\mathrm{Al}_{2} \mathrm{O}_{3}$. Primitive IAB commonly show an increase in $\mathrm{Al}_{2} \mathrm{O}_{3}$ with decreasing $\mathrm{MgO}$, as in the lavas recovered from Hole $839 \mathrm{~B}$ and our 2-kbar experiments. This indicates that plagioclase crystallization is suppressed, and the early stages of fractional crystallization are dominated by ferromagnesian silicates. Sisson and Grove (1993b) modeled the crystallization of high-MgO Aleutian basalts to produce low- $\mathrm{MgO}$ high-alumina basalts, and found that it required crystallization of high-Ca pyroxene and olivine in approximate proportions 85:15, before plagioclase saturation. Lavas containing high-Ca clinopyroxene and olivine in the approximate volume proportions 75:25 (arc ankaramites) have been reported from Merelava and Epi volcanoes in the Vanuatu arc by Barsdell (1988) and Barsdell and Berry (1990), respectively. Merelava Volcano is located at the southern end of the Northern Trough, a young backarc basin, whereas Epi is located along the volcanic front (Dubois et al., 1978). Table 5 compares the composition of Sample 135-839B-15R-2, 63-67 cm, the starting material for our melting experiments, with whole-rock and groundmass analyses of the most primitive lavas from Merelava (BC 13) and Epi (71046). All three lavas display similar depletions in $\mathrm{TiO}_{2}, \mathrm{Al}_{2} \mathrm{O}_{3}$ and $\mathrm{Na}_{2} \mathrm{O}$, and high $\mathrm{K}_{2} \mathrm{O}$. The Vanuatu lavas display crystallization sequences similar to that produced in our $\mathrm{H}_{2} \mathrm{O}$-saturated experiments, with early crystallization of high-Ca clinopyroxene and olivine, followed by an assemblage consisting of olivine, high-Ca clinopyroxene, and plagioclase. The chemistry of phenocrysts in these lavas is comparable with those produced in our 2-kbar experiments, with Wo-rich high-Ca clinopyroxene $\left(\mathrm{Wo}_{46.5} \mathrm{En}_{50} \mathrm{Fs}_{3.5}\right.$ to $\mathrm{Wo}_{38} \mathrm{En}_{45} \mathrm{Fs}_{17}$ from Merelava; $\mathrm{Wo}_{47} \mathrm{En}_{47.2} \mathrm{Fs}_{5.8}$ to $\mathrm{Wo}_{44.9} \mathrm{En}_{43.8} \mathrm{Fs}_{11.3}$ from Epi), and An-rich plagioclase $\left(\mathrm{An}_{91}\right.$ from Merelava; $\mathrm{An}_{94.6}$ from Epi). These similarities are evidence that the Vanuatu lavas underwent crystallization in the crust with high pre-eruptive $\mathrm{H}_{2} \mathrm{O}$ contents $(2-4 \mathrm{wt} \%)$.

\section{Comparison of Experimental Results with Lavas Recovered from Hole 839B}

The pseudo-ternary diagrams in Figure 3 compare the whole-rock compositions of lavas recovered from Hole $839 \mathrm{~B}$ with experimentally determined phase boundaries. The lavas have been divided into three groups, based on $\mathrm{MgO}$ content. High- $\mathrm{MgO}$ lavas ( $14 \mathrm{wt} \%$; squares) include Units 3, 4, and 6; medium-MgO lavas ( $~ 9 \mathrm{wt} \%$; triangles) are from Unit 1 ; and low-MgO lavas ( $4.5 \mathrm{wt} \%$; circles) include Units 2 , 5,7 , and 9 . No simple stratigraphic relationship exists between lava $\mathrm{MgO}$ content and position in the drill core. Medium $\mathrm{MgO}$ lavas are on top, high $\mathrm{MgO}$ in the middle, and low $\mathrm{MgO}$ are at the base of Hole 839B (Parsons, Hawkins, Allan, et al., 1992). This indicates that a direct relationship between the three groups through fractional crystallization is unlikely, but it does not preclude the possibility that the

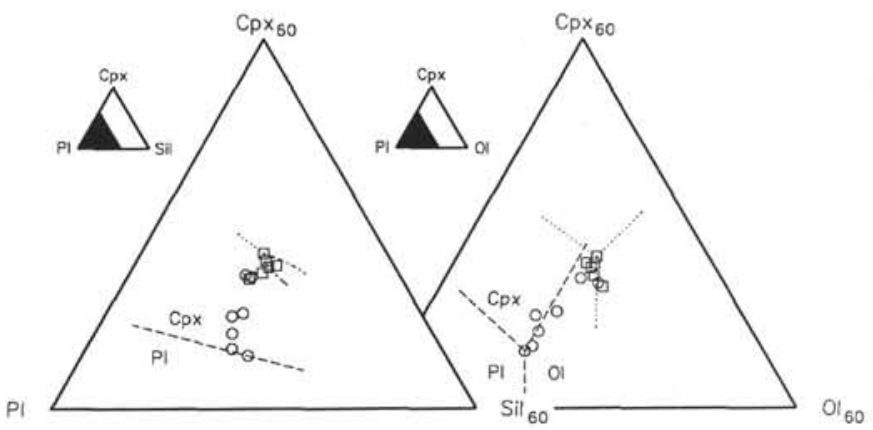

Figure 2. Glass compositions from anhydrous (squares) and water-saturated (circles) experiments recalculated into mineral components (OI-Cpx- $\left.\mathrm{Pl}-\mathrm{SiO}_{2}\right)$, using the scheme of Tormey et al. (1987), and projected from Ol onto the $\mathrm{PI}-\mathrm{Cpx}-\mathrm{SiO}_{2}$ pseudo-ternary (left) and from $\mathrm{SiO}_{2}$ onto the $\mathrm{PI}-\mathrm{Cpx}$-Ol pseudoternary (right). Experimentally determined phase boundaries are shown as dotted ( $1 \mathrm{~atm}$, anhydrous) and dashed $\left(2 \mathrm{~kb}, \mathrm{H}_{2} \mathrm{O}\right.$-saturated) curves.

PI

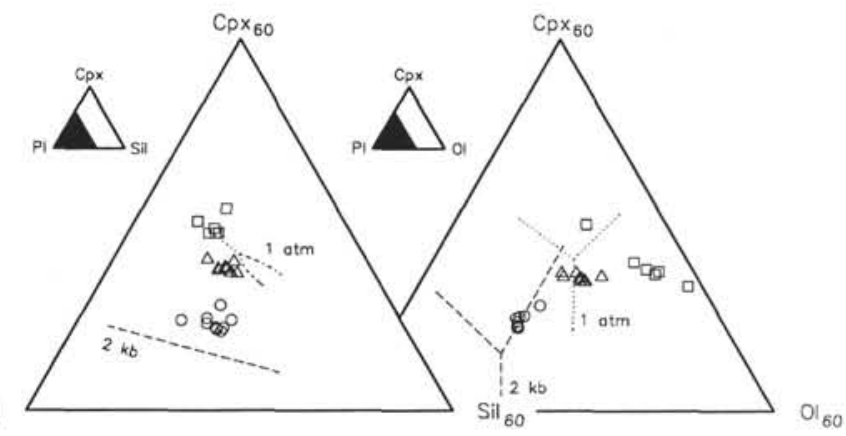

Figure 3. Comparison of Hole $839 \mathrm{~B}$ lavas with experimentally determined phase boundaries in the projection from $\mathrm{Ol}$ onto the $\mathrm{Pl}-\mathrm{Cpx}-\mathrm{SiO}_{2}$ pseudoternary (left) and from $\mathrm{SiO}_{2}$ onto the $\mathrm{Pl}-\mathrm{Cpx}$-Ol pseudo-ternary (right). Lavas are divided into three groups: high- $\mathrm{MgO}(\sim 14 \mathrm{wt} \%$; squares), medium-MgO ( $\sim 9 \mathrm{wt} \%$; triangles) and low- $\mathrm{MgO}(\sim 4.5 \mathrm{wt} \%$; circles).

parent for the low $\mathrm{MgO}$ lavas was similar in composition to the medium or high $\mathrm{MgO}$ samples.

Interpreting the compositional variations for a suite of lavas based on analyses of whole rocks is often complicated by the effects of crystal accumulation. This is especially true for lavas with arc affinities, given that they frequently contain a significant proportion of phenocrysts (up to $\sim 50 \mathrm{vol} \%$ ). Only in cases where crystals have been retained in the proportions in which they crystallized from the magma does the whole-rock composition of a phyric lava represent a liquid. The compositions of lavas from Hole $839 \mathrm{~B}$ show a general decrease in $\mathrm{Cpx}$ component with decreasing $\mathrm{MgO}$ content in the projection from Ol onto the PI-Cpx-SiO ${ }_{2}$ pseudo-ternary (Fig. 3; left). Overprinting this trend is a scattering of the data in the direction of the silica apex. A decrease in both $\mathrm{Cpx}$ and $\mathrm{Ol}$ components with decreasing $\mathrm{MgO}$ is evident in the Pl-Cpx-Ol pseudo-ternary (Fig. 3; right), overprinted by scattering toward the $\mathrm{Ol}$ apex. These correlations indicate that olivine and high-Ca clinopyroxene are controlling variations in lava compositions, and may be interpreted as either crystallization along the $\mathrm{Ol}+\mathrm{Cpx}$ boundary or as accumulation of olivine or olivine + high-Ca clinopyroxene crystals.

Figure 4 compares analyses of the glassy chill margins of pillows, which represent liquid compositions, from lavas from Units 3, 4, 6 (high-MgO), 2, and 9 (low-MgO) (Hergt and Nilsson, this volume) with our experimentally determined phase boundaries, and the fields of whole-rock compositions. The glass compositions from the high$\mathrm{MgO}$ lavas (squares) define a trend consistent with crystallization along the $2 \mathrm{kbar}, \mathrm{H}_{2} \mathrm{O}$-saturated experimentally determined $\mathrm{Ol}+\mathrm{Cpx}$ 


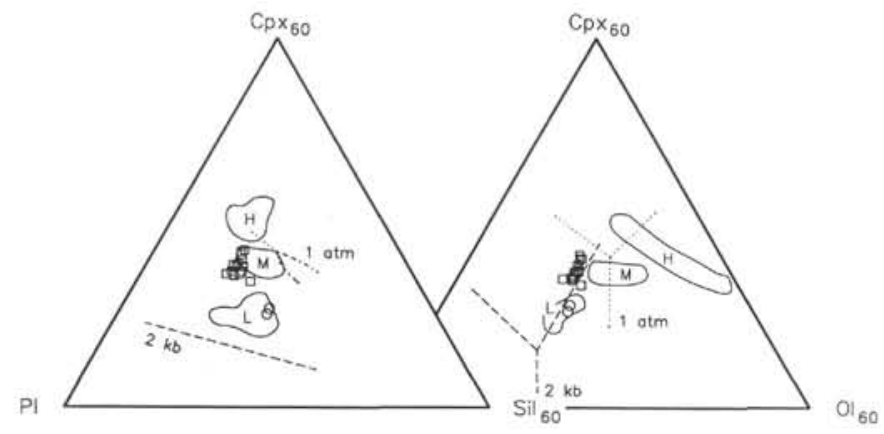

Figure 4. Comparison of analyses of glassy pillow rinds from high- $\mathrm{MgO}$ (squares) and low-MgO (circles) lavas from Hole 839B (Hergt and Nilsson, this volume) with experimentally determined phase boundaries and lava whole-rock compositions $(\mathrm{H}=$ high $-\mathrm{MgO}, \mathrm{M}=$ medium $\mathrm{MgO}$, and $\mathrm{L}=$ low- $\mathrm{MgO})$ in the $\mathrm{Pl}-\mathrm{Cpx}-\mathrm{SiO}_{2}$ (left) and $\mathrm{Pl}-\mathrm{Cpx}-\mathrm{Ol}$ (right) pseudo-ternaries.

saturation boundary. The field of high- $\mathrm{MgO}$ whole-rock compositions are enriched in $\mathrm{Ol}$ and $\mathrm{Cpx}$, relative to the glasses, and define a trend indicating strong olivine control. Xenocrysts of olivine $\left(\mathrm{Fo}_{90}\right)$ and chromian spinel have been identified in Unit 3 lavas (Bryan et al., this volume). We propose that the high-MgO lavas represent liquids saturated with olivine and high-Ca clinopyroxene that have been affected by accumulation of olivine and chromian spinel.

To test this model, we first calculated a probable parent magma for the high- $\mathrm{MgO}$ lavas, based on the results of our 2-kbar, $\mathrm{H}_{2} \mathrm{O}$-saturated experiments, and then performed mass balance calculations involving the calculated parent, high-MgO lavas and xenocrystic olivine and chromian spinel compositions from Bryan et al. (this volume). The parent composition was calculated by "back fractionating" the glass composition from Experiment \#12 $\left(1050^{\circ} \mathrm{C}\right.$; Table 3$)$ along the $\mathrm{Ol}+$ Cpx saturation boundary, initially using the compositions of the experimentally produced high-Ca pyroxene and olivine. These phases were added to the melt in the constant proportions 78:22, and their compositions were adjusted to be in equilibrium with the melt composition, based on the experimentally determined exchange $K_{D}$ 's, after every $2 \%$ addition. The calculations were continued until the melt was in equilibrium with $\mathrm{Fo}_{89}$ olivine, which required the addition of $35 \%$ crystals. The resulting parent composition is as follows:

\begin{tabular}{llllllll}
\hline $\mathrm{SiO}_{2}$ & $\mathrm{TiO}_{2}$ & $\mathrm{Al}_{2} \mathrm{O}_{3}$ & $\mathrm{FeO}$ & $\mathrm{MgO}$ & $\mathrm{CaO}$ & $\mathrm{Na}_{2} \mathrm{O}$ & $\mathrm{K}_{2} \mathrm{O}$ \\
53.10 & 0.57 & 13.18 & 7.70 & 11.20 & 12.70 & 1.22 & 0.23 \\
\hline
\end{tabular}

The mass balance calculations involving this liquid and the xenocrystic olivine and chromian spinel compositions indicate that the range of observed high- $\mathrm{MgO}$ compositions can be generated by addition of the 5-16 wt $\% \mathrm{Fo}_{90}$ olivine and 3-4 wt \% chromian spinel to the inferred high- $\mathrm{MgO}$ parent (Table 6).

The whole-rock analyses of the medium- $\mathrm{MgO}$ lavas plot close to the glass analyses and are therefore interpreted to be close to liquid compositions. Our 2-kbar experiments on Sample 135-839B-15R-2, 63-67 cm, a medium-MgO lava, produced a few percent crystallization of olivine and chromian spinel before reaching the $\mathrm{Ol}+\mathrm{Cpx}$ saturation boundary, consistent with minor accumulation of olivine. The field of medium- $\mathrm{MgO}$ lava compositions is elongate toward the $\mathrm{Ol}$ apex in the $\mathrm{Pl}-\mathrm{Cpx}-\mathrm{Ol}$ pseudo-ternary (Fig. 4; right), evidence consistent with olivine addition, although considerably less olivine addition is required than in the case of the high-MgOlavas. Therefore, we interpret the medium- $\mathrm{MgO}$ lavas to represent liquids saturated with olivine and high-Ca pyroxene that have experienced, at most, a few percent addition of olivine ( \pm chromian spinel).

The two available glass analyses from the low-MgO lavas plot in the same area as the whole-rock analyses (Fig. 4), indicating that
Table 5. Comparison of Sample 135-839B-15R-2, 63-67 cm, with whole-rock and groundmass analyses of similar lavas from Merelava (Barsdell, 1988) and Epi (Barsdell and Berry, 1990) in the Vanuatu arc.

\begin{tabular}{|c|c|c|c|c|c|}
\hline & $\begin{array}{c}\text { Sample } \\
135-839 \mathrm{~B}-15 \mathrm{R}-2, \\
63-67 \mathrm{~cm}\end{array}$ & $\mathrm{BC} 13$ & $\begin{array}{c}\text { BC } 13 \\
\text { groundmass }\end{array}$ & 71046 & $\begin{array}{c}71046 \\
\text { groundmass }\end{array}$ \\
\hline $\mathrm{SiO}_{2}$ & $53.3(2)$ & 50.2 & 50.8 & 48.2 & 48.2 \\
\hline $\mathrm{TiO}_{2}^{2}$ & $0.60(3)$ & 0.46 & 0.71 & 0.39 & 0.67 \\
\hline $\mathrm{Al}_{2} \mathrm{O}_{3}$ & $15.16(8)$ & 10.3 & 15.2 & 11.5 & 16.2 \\
\hline $\mathrm{FeO}{ }^{3}$ & $8.85(8)$ & 8.09 & 9.00 & 8.91 & 9.81 \\
\hline $\mathrm{MnO}$ & $0.22(2)$ & 0.17 & 0.16 & 0.16 & 0.16 \\
\hline $\mathrm{MgO}$ & $9.36(5)$ & 13.71 & 8.82 & 13.50 & 8.00 \\
\hline $\mathrm{CaO}$ & $11.3(1)$ & 13.69 & 11.8 & 14.4 & 13.3 \\
\hline $\mathrm{Na}_{2} \mathrm{O}$ & $1.48(5)$ & 1.6 & 2.09 & 1.05 & 1.88 \\
\hline $\mathrm{K}_{2} \mathrm{O}$ & $0.30(2)$ & 0.38 & 0.48 & 0.31 & 0.48 \\
\hline Total & 100.57 & 98.60 & 99.06 & 98.42 & 98.70 \\
\hline
\end{tabular}

Table 6. Least-squares mass balance models relating calculated parent magma composition with high$\mathrm{MgO}$ lava whole-rock compositions through accumulation of olivine and chromian spinel.

\begin{tabular}{ccrrr}
\hline $\begin{array}{c}\text { High-MgO lava } \\
\text { sample }\end{array}$ & $\begin{array}{c}\text { Parent } \\
(w t \%)\end{array}$ & $\begin{array}{c}\text { Olivine } \\
\text { (wt\%) }\end{array}$ & $\begin{array}{r}\text { Chromian } \\
\text { spinel } \\
\text { (wt\%) }\end{array}$ & $\Sigma \mathrm{R}^{2}$ \\
\hline 135-839B- & & & & \\
27R-1, 21-24 cm & 90.99 & 5.51 & 3.15 & 0.6444 \\
19R-1, 50-56 cm & 90.45 & 6.46 & 3.13 & 0.3192 \\
23R-1, 22-27 cm & 88.42 & 7.75 & 3.85 & 0.2006 \\
20R-1, 74-80 cm & 87.51 & 8.80 & 3.59 & 0.1092 \\
24R-1, 14-19 cm & 81.23 & 15.93 & 2.80 & 0.5577 \\
\hline
\end{tabular}

they have not been significantly affected by crystal accumulation. The low-MgO lavas are displaced toward the 2-kbar, $\mathrm{H}_{2} \mathrm{O}$-saturated boundary, relative to the anhydrous phase boundaries in the $\mathrm{Pl}-\mathrm{Cpx}$ $\mathrm{SiO}_{2}$ pseudo-ternary; and they appear to fall along a $\mathrm{Cpx}+\mathrm{Pl} \pm \mathrm{Ol} \pm$ Opx saturation boundary (Fig. 3; left). The projected low-MgO lava compositions cluster in a narrow region in the $\mathrm{Pl}-\mathrm{Cpx}-\mathrm{Ol}$ pseudoternary (Fig. 3; right) that represents a $\mathrm{Cpx}+\mathrm{Pl} \pm \mathrm{Ol} \pm \mathrm{Opx}$ saturation boundary. This boundary is close to the $2-\mathrm{kbar}, \mathrm{H}_{2} \mathrm{O}$-saturated boundary, but it is displaced slightly toward the 1-atm boundary. Both projections are consistent with the low- $\mathrm{MgO}$ lavas crystallizing at $\sim 1.5 \mathrm{kbar}, \mathrm{H}_{2} \mathrm{O}$-saturated, or near $2 \mathrm{kbar}$ at conditions that were not quite $\mathrm{H}_{2} \mathrm{O}$-saturated. The presence of plagioclase phenocrysts with Ca-rich cores $\left(\mathrm{An}_{90}\right)$ in the low-MgO lavas (Bryan et al., this volume) implies a Ca-Na exchange $\mathrm{K}_{\mathrm{D}}$ of $\sim 3.1$, a further indication of elevated pre-eruptive $\mathrm{H}_{2} \mathrm{O}$ contents in these lavas.

Figure 5 is a schematic, showing the major processes involved in the petrogenesis of Hole 839B lavas. Variable amounts of fractional crystallization along the $\mathrm{OI}+\mathrm{Cpx}$ saturation boundary under hydrous conditions, represented by the solid curves in both the $\mathrm{Pl}-\mathrm{Cpx}-\mathrm{SiO}_{2}$ (left) and $\mathrm{Pl}-\mathrm{Cpx}-\mathrm{Ol}$ (right) pseudo-ternaries, produced a spread in the lavas from high- $\mathrm{MgO}$ (field labeled $\mathrm{H}$ ) through medium- (field labeled M) to low- $\mathrm{MgO}$ (field labeled $\mathrm{L}$ ) lavas. The accumulation of olivine and chromian spinel caused a spread within high- and medium- $\mathrm{MgO}$ lava compositions toward the $\mathrm{Ol}$ apex of the $\mathrm{Pl}-\mathrm{Cpx}-\mathrm{Ol}$ pseudo-ternary. The low-MgO lavas have reached plagioclase saturation, and possibly the olivine-out reaction point, and evolved along the $\mathrm{Cpx}+\mathrm{Pl} \pm \mathrm{Ol} \pm$ Opx saturation boundary (solid curve labeled $\mathrm{Cpx}+\mathrm{Pl} \pm \mathrm{Ol} \pm \mathrm{Opx}$ in the $\mathrm{Pl}-\mathrm{Cpx}-\mathrm{Ol}$ pseudo-ternary).

The compositions of high-Ca pyroxene and plagioclase phenocrysts analyzed in Unit 1 (medium-MgO) lavas are consistent with high pre-eruptive $\mathrm{H}_{2} \mathrm{O}$ contents. The high-Ca clinopyroxenes analyzed in Samples 135-839B-15R-3, 72-76 cm, and 135-839B-14R-2, $\mathrm{I}-8 \mathrm{~cm}$, are close in composition to those produced in our 2-kbar, $\mathrm{H}_{2} \mathrm{O}$-saturated experiments (Tables $3-4$ and Fig. 1), with $\sim 20 \mathrm{wt} \%$ $\mathrm{CaO}$, whereas the 1 -atm, anhydrous experiments produced augites 


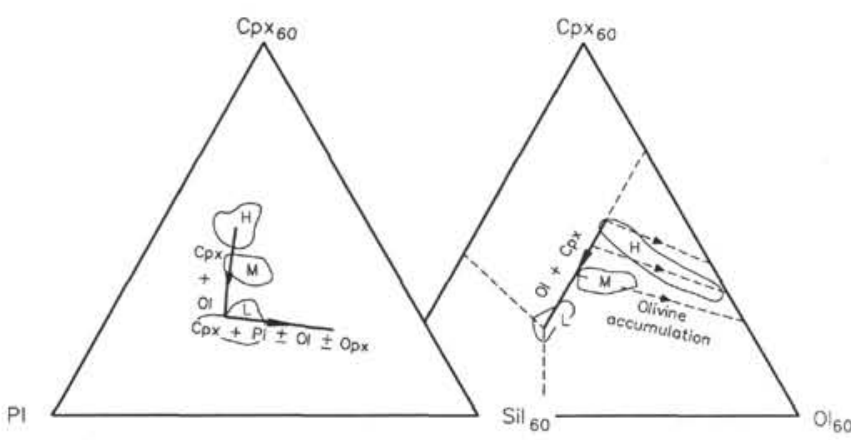

Figure 5. Schematic diagram showing the major processes involved in the petrogenesis of Hole 839B lavas, in the $\mathrm{Pl}-\mathrm{Cpx}-\mathrm{SiO}_{2}$ (left) and $\mathrm{Pl}-\mathrm{Cpx}-\mathrm{Ol}$ (right) pseudo-ternaries. Heavy arrowed lines indicate fractional crystallization. Dashed arrowed lines indicate crystal accumulation. Inferred phase boundaries are shown as dashed lines. Fields of lava whole-rock compositions are labeled as in Figure 4.

with only $\sim 18 \mathrm{wt} \% \mathrm{CaO}$ (Table 2). The cores of plagioclase phenocrysts from these samples are consistently $\mathrm{An}$-rich $\left(\mathrm{An}_{89}\right.$ in Sample 135-839B-15R-3, 72-76 cm, and $\mathrm{An}_{91}$ in Sample 135-839B-14R-2, $1-8 \mathrm{~cm}$ ). This indicates a Ca-Na exchange $K_{D}$ of $\sim 2$, assuming that crystal accumulation has not affected the whole-rock $\mathrm{Ca} / \mathrm{Na}$ ratio. $\mathrm{A}$ $\mathrm{K}_{\mathrm{D}}$ of 2 indicates $\sim 2 \mathrm{wt} \% \mathrm{H}_{2} \mathrm{O}$, based on the experiments of Baker and Eggler (1987). The simplest explanation for the observations of coexisting olivine + high-Ca clinopyroxene phenocrysts, minor Anrich plagioclase rimmed by more Na-rich plagioclase, and orthopyroxene cored by olivine is that the magma was initially $\mathrm{H}_{2} \mathrm{O}$ rich $(\sim 4-5$ wt \%), and it underwent at least two episodes of volatile loss. The initial change in volatile content stabilized a minor amount of An-rich plagioclase, producing the assemblage found in Sample 135-839B$15 \mathrm{R}-3,72-76 \mathrm{~cm}$. Crystallization along the $\mathrm{OI}+\mathrm{Cpx}+\mathrm{Pl}$ boundary over any significant temperature interval would have produced more plagioclase than is present in thin section and is therefore unlikely. Further volatile loss, caused by low-pressure crystallization, stabilized orthopyroxene relative to olivine, less calcic augite, and a more albite-rich plagioclase, producing the assemblage observed in Sample 135-839B-14R-2, 1-8 cm.

\section{CONCLUSIONS}

On the basis of natural and experimental evidence, we conclude that the chemical variations in Hole $839 \mathrm{~B}$ lavas result primarily from hydrous fractional crystallization at crustal level pressures. A positive correlation between $\mathrm{Al}_{2} \mathrm{O}_{3}$ and $\mathrm{SiO}_{2}$, which distinguishes these backarc lavas from others recovered during Leg 135 , results from the suppression of plagioclase crystallization caused by high pre-eruptive $\mathrm{H}_{2} \mathrm{O}$ contents. The dominant control on melt composition is crystallization, under hydrous conditions, of high-Ca clinopyroxene and olivine in approximately 78:22 proportions; evidence also exists for variable amounts of olivine and chromian spinel accumulation. Low$\mathrm{MgO}$ lavas from Hole $839 \mathrm{~B}$ likely evolved through crustal level fractional crystallization, under hydrous conditions, from a parent similar to basaltic andesite Sample 135-839B-15R-2, 63-67 cm.

Lavas from Hole 839B are estimated to have had pre-eruptive $\mathrm{H}_{2} \mathrm{O}$ contents of $\sim 4 \mathrm{wt} \%$. The medium-MgO lavas underwent an episode of volatile loss, decreasing their $\mathrm{H}_{2} \mathrm{O}$ content to $\sim 2 \mathrm{wt} \%$ and stabilizing orthopyroxene and plagioclase phenocrysts. This loss of volatiles may have accompanied ascent of the magma into the shallow crust just before eruption.

\section{ACKNOWLEDGMENTS}

The authors thank Dave Walker and Roger Nielsen for reviews, and Kristin Nilsson for advance access to Hole 839B glass analyses.
This research was supported by NSF grants OCE-9115901 and EAR9204661. Mike Jercinovic expertly maintained the MIT electron microprobe facility where the phenocrysts and experimental run products where analyzed.

\section{REFERENCES}

Albee, A.L., and Ray, L., 1970. Correction factors for electron microprobe analysis of silicates, oxides, carbonates, phosphates and sulfates. Anal. Chem., 42:1408-1414.

Baker, D.R., and Eggler, D.H., 1987. Compositions of anhydrous and hydrous melts coexisting with plagioclase, augite and olivine or low-Ca pyroxene from $1 \mathrm{~atm}$ to $8 \mathrm{kbar}$ applications to the Aleutian volcanic center of Atka. Am. Mineral., 72:12-28.

Barsdell, M., 1988. Petrology and petrogenesis of clinopyroxene-rich tholeiitic lavas, Merelava Volcano, Vanuatu. J. Petrol., 29:927-964.

Barsdell, M., and Berry, R.F., 1990. Origin and evolution of primitive island arc ankaramites from western Epi, Vanuatu. J. Petrol., 31:747-777.

Bence, A.E., and Albee, A.L., 1968. Empirical correction factors for the electron microanalysis of silicates and oxides. J. Geol., 76:382-403.

Biggar, G.M., 1972. Diopside, lithium metasilicate and the 1968 temperature scale. Mineral. Mag., 38:768-770.

Bryan, W.B., Finger, L.W., and Chayes, F. 1969. Estimating proportions in petrographic mixing equations by least squares approximations. Science, 163:926-927.

Dubois, J., Dugas, J., Lapouille, A., and Louat, R., 1978. The troughs at the rear of the New Hebrides Island arc: possible mechanisms of formation. Can. J. Earth Sci., 15:351-360.

Gill, J.B., 1981. Orogenic Andesites and Plate Tectonics: New York (Springer-Verlag).

Grove, T.L., 1981. Use of FePt alloys to eliminate the iron loss problem in I atmosphere gas mixing experiments: theoretical and practical considerations. Contrib. Mineral. Petrol., 78:298-304.

Grove, T.L., and Baker. M.B., 1984. Phase equilibrium controls on the tholeiitic versus calc-alkaline differentiation trends. J. Geophys. Res., 89:3253-3274

Grove, T.L., and Bryan. W.B., 1983. Fractionation of pyroxene-phyric MORB at low pressure: an experimental study. Contrib. Mineral. Petrol., 84:293309.

Grove, T.L., Kinzler, R.J., and Bryan. W.B., 1990. Natural and experimental phase relations of lavas from Serocki Volcano. In Detrick, R., Honnorez, J., Bryan, W.B., Juteau, T., et al., Proc. ODP, Sci. Results, 106/109: College Station, TX (Ocean Drilling Program), 9-17.

Hart, S.R., Glassley, W.A., and Karig, D.E., 1972. Basalts and seafloor spreading behind the Mariana Island arc. Earth Planet. Sci. Lett., 15:12-18.

Parson, L.. Hawkins, J., Allan, J., et al., 1992. Proc. ODP, Init. Repts., 135: College Station, TX (Ocean Drilling Program).

Perfit, M.R., Gust, D.A., Bence, A.E., Arculus, R.J., and Taylor, S.R., 1980. Chemical characteristics of island-arc basalts: implications for mantle sources. Chem. Geol., 30:227-256.

Poldervaart, A., and Hess, H.H., 1951. Pyroxenes in the crystallization of basaltic magma. J. Geol., 59:472-489.

Roeder. P.L., and Emslie. R.F., 1970. Olivine-liquid equilibrium. Contrib. Mineral. Petrol., 29:275-289.

Sisson, T.W., and Grove, T.L., 1993a. Experimental investigations of the role of $\mathrm{H}_{2} \mathrm{O}$ in calc-alkaline differentiation and subduction zone magmatism. Contrib. Mineral. Petrol., 113:143-166.

1993b. Temperatures and $\mathrm{H}_{2} \mathrm{O}$ contents of low-MgO high-alumina basalts. Contrib. Mineral. Petrol., 113:167-184.

Tormey, D.R., Grove, T.L.. and Bryan. W.B., 1987. Experimental petrology of normal MORB near the Kane Fracture Zone: $22^{\circ}-25^{\circ} \mathrm{N}$, Mid-Atlantic Ridge. Contrib. Mineral. Petrol., 96:121-139.

\footnotetext{
Abbreviations for names of organizations and publication titles in ODP reference lists follow the style given in Chemical Abstracts Service Source Index (published by American Chemical Society).
}

Date of initial receipt: 30 June 1992

Date of acceptance: 3 December 1992

Ms 135SR-133 